\title{
Oxidative Stress Biomarkers in Dystrophic Lambs and Kids in Relation to Body Condition
} Scores

\author{
Yasmin H. Bayomi $^{1^{*}}$, Wafaa A.M. Mohamed ${ }^{2}$ and Abdel Karem M. Morsi ${ }^{1}$ \\ ${ }^{1}$ Animal Medicine Department (Internal Medicine), Faculty of Veterinary Medicine, Zagazig \\ University, 44511, Egypt \\ ${ }^{2}$ Clinical Pathology Department, Faculty of Veterinary Medicine, Zagazig University, 44511, \\ Egypt
}

\begin{abstract}
This study was conducted to investigate the relationship between the severity of muscular dystrophy, caused by vitamin $\mathrm{E}$ and selenium deficiencies in lambs and kids, and their body condition score (BCS). A total of 71 lambs and kids aged from 1-6 months were used; 51 dystrophic animals (38 lambs and 13 kids) and 20 healthy ones (10 lambs and 10 kids). The animal grouping was done on the basis of BCS and the obtained hematological and biochemical alterations. Blood samples were collected after clinical examination to all animals, for performing the clinicopathological studies. Results showed that the incidence and severity of the disease were higher in rapidly growing and well-nourished lamb (BCS 3.5-4), while the occurrence of the disease in kids was more common in BCS 1-2.5. Regarding biochemical findings, the serum vitamin E, Se, CAT and GSH-Px recorded lower values in dystrophic lambs and kids than the control, while higher values of CPK, CTn I, MDA and NO were recorded with the strongest alterations in good bodily conditioned ones. A significant decrease in serum $\mathrm{Mg}$ level in dystrophic kids with BCS 1-3 was also observed. In conclusion, proper nutrition of dam and young without shortage or excess is necessary. Also, vitamin E and se supplementation should be increased in good bodily conditioned and rapidly growing animals than their counterparts to activate the antioxidant system and reduce oxidative stress.
\end{abstract}

Keywords: BCS, Lambs, Kids, Vitamin E deficiency, Oxidative stress

\section{Introduction:}

Economically, sheep and goats are considered one of the most important livestock in Egypt. They can be raised by the poor farmer because they are relatively cheaper than other livestock and have short lambing and kidding interval with a high incidence of twins, sometimes triples [1]. On the nutritional side, sheep and goats are considered sweeper animals because they graze the crop residues after harvest. In spite the last benefit, proper nutrition should be applied to avoid nutritional deficiency diseases. Vitamin E and Selenium (Se) deficiency named stiff -lamb disease (SLD)or nutritional muscular dystrophy (NMD) considered one of the most important nutritional deficiency diseases affect small ruminants [2,3]. Vitamin $\mathrm{E}$ ( $\alpha$-tocopherol) is a major lipid-soluble antioxidant vitamin and selenium ( $\mathrm{Se}$ ) is a cofactor for glutathione peroxidase (GSH-Px) enzyme [4,5] which together act as a biological antioxidant that eliminates the reactive oxygen species (ROS) and prevents the cellular oxidative damage resulted from membrane lipid peroxidation [6].

NMD has different condition such as white muscle disease (WMD) or also known as stifflamb disease that occur in lambs up to 3 months of age, congenital WMD in newborn lambs which may dead recently or shortly after birth, delayed WMD occurs in lambs of 1-3 months of age which affect limbs, weaned ill thrift which characterized by poor growth rates and decreased wool production, Se- responsive scouring and finally ewe infertility [7].

Scott [8] mentioned that nutritional muscular dystrophy typically affects rapidly growing 2-6 wks old lambs, the disease characterized by sudden onset of stiffness, reluctant to move as they are easily caught while others in the group gallop around, lambs are bright, alert and suckle well but have a painful expression with the head held lowered. One or two days later, affected lambs are 
unable to rise and remain in the sternal recumbency.

Ghanem et al. [9] stated that the most observed signs of muscular dystrophy in lamb were ill-thriftiness, weakness, depression, stiffness in gait, knuckling at fetlock joint, sternal recumbency, inability to stand, trembling if the animal forced to stand, while the changes in the vital signs were dyspnea, tachycardia, and irregular heart beat "arrhythmia".

Hence the occurrence of muscular dystrophy was considered with rapidly growing animals, we noticed that if twin lamb or goat kid under the same condition develops muscular dystrophy, the symptoms were aggravated in good bodily conditioned one.

Body condition scoring is a simple method for evaluating the performance of an animal, it can be easily applied clinically and it can be used for all ages of animals. Routine BCS is important for evaluating the current and past feeding program; it can help to detect any potential problem that might cause a serious problem, especially those related to the nutrition. A body condition scoring system for sheep and goats were recognized according to Pennington [10] and Koyuncu and Altınçekiç, [11] it ranges from 1 to 5 , score of 1 is very thin or emaciated animal and middle point is 3 while score of 5 is a very fat or obese animal, healthy and good nourished animal should not be very fat or very thin.

Both vitamin $\mathrm{E}$ and Se deficiency in lambs and kids based on its BCS are poorly studied so, the present study was established to clarify the relationship between the severity of signs in the dystrophic animals and their BCS.

\section{Material and methods}

\section{Ethical approval}

The protocol of our study was approved by the Ethics Committee of Egyptian Veterinary Medicine Authority.

\section{Animals grouping}

This study started when twin's lambs exhibited signs of muscular dystrophy. Signs were more severe in the good bodily condition one. This study was conducted on 71 lambs and kids; 51 dystrophic animals within 1 to 6 months of age. Animals were admitted to Veterinary Medical Teaching Hospital, Faculty of Veterinary Medicine, Zagazig University, Egypt. The main owner's complaints were stiffness in gait, inability to stand and prefer recumbency.

Animals grouping was done according to BCS; control groups contain 10 lambs (BCS 2.5-4) and 10 kids (BCS 2-3.5), while 38 dystrophic lambs were used with BCS 1-2 (10 case, $26.32 \%$ ), BCS 2-3 (6 case, $15.78 \%$ ), BCS 3-3.5 (15 case, 39.47\%) and BCS 3.5-4 (7 case, $18.42 \%$ ). The dystrophic kids were 13 , of which 6 cases $(46.16 \%)$ with BCS 1-2, 5 cases $(38.46 \%)$ with BCS $2-3$ and two cases $(15.38 \%)$ only with BCS $3 \& 3.5$.

\section{Management and Feeding regime}

Diseased animals either came from small private farms with proper feeding regime, grains, hay and green pasture or from the flocks reared by stockmen where the nutrition of the dam and young animals depends mainly on bad quality hay, remnants of root crops, rice straw ad libitum and rarely barseem. While control ones were belonged to the Animal Production Farm of Faculty of Veterinary Medicine, Zagazig University and they fed a balanced ration, barseem was utilized when available.

\section{Clinical examination}

Clinical examination of all animals was performed; history regarding age, location, feeding regime and observed signs were taken. Physical examination was done, and vital signs were monitored according to Sherman and Robinson [12].

A condition scoring system was then applied to facilitate the comparison among animals. The body condition scoring system was based on visual appraisal and palpation, the condition was evaluated on a scale of 1 to 5 , with 1 being extremely emaciated and 5 being extremely fat. A description of the condition score system was done according to ESGPIP and Technical Bulletin No. 8 [13], the scoring was based on manual palpation of the loin region (located behind the last rib and before the hip bones) in which the degree of 
bony prominence as spinous process and transverse process of lumbar vertebrae can be measured, the second region is the thoracic cavity, ribs, and sternum.

\section{Blood sampling}

For hematological analysis, $2 \mathrm{~mL}$ of blood was collected from the jugular vein of all dystrophic and control animals in tubes with di-potassium salt of ethylene-di-amine-tetraacetic acid (EDTA), and another $5 \mathrm{~mL}$ was obtained in a plane tube (without EDTA), allowed to coagulate at sloped manner for 30 min and centrifuged at 3,000 rpm for $10 \mathrm{~min}$ to separate good and clear straw yellow serum. The obtained serum was stored at $-20^{\circ} \mathrm{C}$ until used for estimation of selective biochemical parameters.

\section{Hematological studies}

In aliquot EDTA-blood, red blood cells (RBCs) count, hemoglobin $(\mathrm{Hb})$ concentration, packed cell volume (PCV), mean corpuscular volume (MCV), mean corpuscular hemoglobin concentration (MCHC) were estimated using full version automatic cell counter (Sysmex KX-21N, Japan) according to the method of Grindem [14].

\section{Biochemical analysis}

Serum vitamin $\mathrm{E}$ and Se were measured at the Central Lab. of Veterinary Medicine Collage, Zagazig University, Egypt using high-performance liquid chromatography according to Chawla and Kaur [15] and atomic absorption spectrophotometer as described by Sunderman and Roszel [16] respectively. The other biochemical parameters were estimated following the methods described at the enclosed pamphlets of manufacturer's kits for magnesium, $\mathrm{Mg}$ [17]; creatine phosphokinase, CPK [18]; cardiac troponin 1, CTn1 [19]; malondialdehyde, MDA [20]; catalase, CAT [21]; glutathione peroxidase, GSH-Px [22] and Nitric oxide, NO [23].

\section{Statistical Analysis}

Data were statistically analyzed by statistical software program (SPSS, version 16) using One Way ANOVAF-test to compare between the dystrophic animals and control one. Mean values \pm SE for each parameter was estimated. Results were considered statistically significant at $\mathrm{P}<0.05$ [24].

\section{Medical intervention}

Affected animals usually respond to vitamin $E$ and selenium injection within few days and able to stand and walk, except one lamb with BCS 4 and1 kids with BCS 1 as their case was deteriorated.

\section{Results \\ Clinical observation}

The most important predisposing factor for stiff lamb disease is unaccustomed exercise, wondering after weaning, the driving of flocks with new lamb and kids long distances. In the same context, kids with hypomagnesemia consider a contributing factor.

Regarding BCS, firstly it is clear that fat deposition in sheep and goat was differed, sheep have more subcutaneous and intramuscular fat, in contrast, and goats have more internal fat. BCS of 1.0 is an extremely thin goat with no fat reserves and a BCS of 5.0 is a very over-conditioned and it is never observed in our study. In our study, healthy kids have BCS of 2.5 to 3.5; meanwhile BCS of $1.0,1.5$, or 2.0 indicate a management or health problem and BCS of $4,4.5$ or 5 was almost never observed in kids under normal management conditions. Healthy lambs usually have BCS 3-4 and BCS under 3 indicates a health problem. Concerning the occurrence of the disease in relation to BCS, the disease was common in lamb with good body condition (BCS 3-4), also it occurs frequently in ill-thrift kids with poor body condition (BCS 1-2).

Clinical findings were summarized in Table 1, Most of the affected animals remain alert with normal appetite, but in severe cases that occur mostly in BCS 4 in lambs and BCS 1-2 in kids, the appetite and alertness may be affected. Symptoms vary from stiffness in gait, to inability to stand and when an attempt was made to help the animal to stand, it mostly trembles with pain, stands on tip-toe and prefers recumbency (Figures 1,2). Lamb and 
kids usually show cardiopulmonary signs including tachycardia (heart rate equal 120190/min), tachyarrhythmias, tachypnea (respiration rate up to $48-65 / \mathrm{min}$ ), dyspnea and wholly abdominal type of respiration while body temperature is usually normal or slightly elevated. Palpation of the affected muscles (shoulder, gluteal and thigh muscle) showed bilateral symmetrical swollen, softness and pain especially in animals with good body condition. While in BCS1-2 the muscles usually atrophied and firm. Of kids, two showed signs of hypomagnesaemia, kids initially show ataxia, stiffness, and hyperexcitability and hyperesthesia to touch, and fall in the ground with paddling, convulsion, and opisthotonus position, by the end of the fits, animal stand and walk on the tip toe and appear on pain.

Table 1: Clinical findings in dystrophic lamb and kids

\begin{tabular}{|c|c|c|c|c|c|}
\hline \multirow[t]{2}{*}{ Parameters } & \multirow[t]{2}{*}{ Clinical Findings } & \multicolumn{2}{|c|}{$\begin{array}{l}\text { Lambs } \\
(38)\end{array}$} & \multicolumn{2}{|c|}{$\begin{array}{l}\text { Kids } \\
\text { (13) }\end{array}$} \\
\hline & & No. & $\%$ & No. & $\%$ \\
\hline Alertness & andAlert with normal appetite & 28 & 73.68 & 8 & 61.53 \\
\hline \multirow[t]{2}{*}{ Appetite } & Alert but need help to eat & 8 & 21.05 & 4 & 30.76 \\
\hline & Depressed with anorexia & 2 & 5.26 & 1 & 7.69 \\
\hline \multirow[t]{5}{*}{ Posture } & Stand with back humped and the limb under the body. & 13 & 34.21 & 5 & 38.46 \\
\hline & Sternal recumbency and unable to stand. & 25 & 65.78 & 8 & 61.53 \\
\hline & Make an attempt to stand and stand with trembling. & 20 & 52.63 & 8 & 61.53 \\
\hline & Standing on tip-toe & 36 & 94.73 & 13 & 100 \\
\hline & Lateral recumbency with consciousness & 2 & 5.26 & 0 & 0 \\
\hline \multirow[t]{5}{*}{ Gait } & Reluctant to move & 30 & 78.94 & 13 & 100 \\
\hline & Stiffness in gait & 30 & 78.94 & 13 & 100 \\
\hline & Walking in the tip toe & 36 & 94.73 & 13 & 100 \\
\hline & knuckling at the fetlocks & 7 & 18.42 & 5 & 38.46 \\
\hline & $\begin{array}{l}\text { Elevation of the two scapulae above the level of back and attach each } \\
\text { other during walking. }\end{array}$ & 32 & 84.21 & 9 & 69.23 \\
\hline \multirow{7}{*}{$\begin{array}{c}\text { Vital signs } \\
\text { alterations }\end{array}$} & Pulse Tachycardia & 31 & 81.57 & 13 & 100 \\
\hline & Tachyarrhythmias & 7 & 18.42 & 0 & 0 \\
\hline & Resp. Tachypnoea & 38 & 100 & 13 & 100 \\
\hline & Dyspnoea and labored respiration & 25 & 65.78 & 9 & 69.23 \\
\hline & Wholly abdominal respiration & 25 & 65.78 & 9 & 69.23 \\
\hline & Temp.Normal temperature & 30 & 78.94 & 11 & 84.61 \\
\hline & Slightly elevated temperature & 8 & 21.05 & 2 & 15.38 \\
\hline \multirow{9}{*}{$\begin{array}{c}\text { Color of } \\
\text { mucous } \\
\text { membrane } \\
\text { Palpation of } \\
\text { muscle } \\
\text { Other } \\
\text { alterations }\end{array}$} & Light rose & 33 & 86.84 & 6 & 46.15 \\
\hline & Pale & 5 & 13.15 & 6 & 46.15 \\
\hline & Slightly congested & 0 & 0 & 1 & 7.69 \\
\hline & Bilateral symmetrical enlargement and softness & 29 & 76.31 & 2 & 15.38 \\
\hline & Atrophied and firm & 9 & 23.68 & 11 & 84.61 \\
\hline & Ill -thrift with additional & & & & \\
\hline & signs of hypomagnesemia. & 4 & 10.52 & 11 & 84.61 \\
\hline & signs of copper deficiency. & 0 & 0 & 3 & 23.0 \\
\hline & signs of iron deficiency & 8 & 21.05 & 8 & 61.53 \\
\hline
\end{tabular}

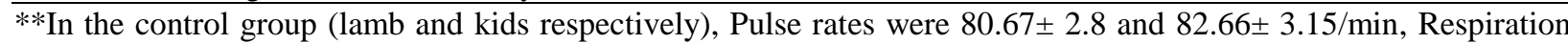
rates were $20.8 \pm 0.058$ and $21.4 \pm 0.46 / \mathrm{min}$ and temperature were $39.4 \pm 0.08$ and $39.5 \pm 0.05 \mathrm{C}$. 

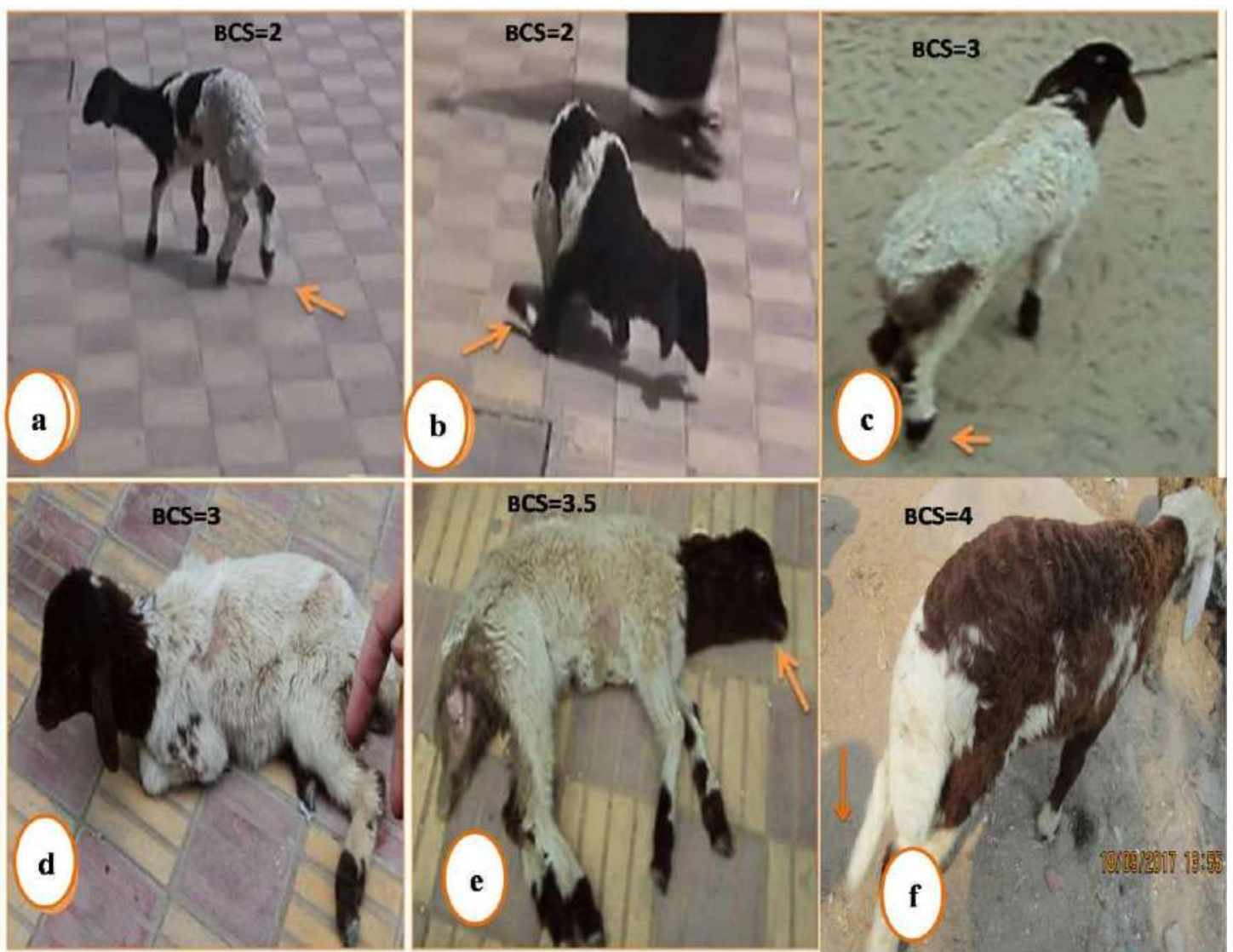

Figure 1: Lambs with different BCS, showing typical signs of stiff- lamb disease; walk in tip-toe (a), prefer recumbency $(b)$, stand on tip-toe $(c, f)$, sternal recumbency $(d)$ and lateral recumbency with tachypnoea and mouth breathing (e).

\section{Hematological findings}

As localized in Table (2) compared to control group, the dystrophic lambs and kids in different body condition scores showed a significant $(\mathrm{P} \leq 0.05)$ decrease in the values of
RBCs, $\mathrm{Hb}, \mathrm{PCV}$ and $\mathrm{MCHC}$ and significant increase $(\mathrm{P} \leq 0.05)$ in $\mathrm{MCV}$. The severity of anemia was higher in ill thrift animals with decreased condition than those in good body condition (BCS 3-4 in lamb and 3-3.5 in kids).

Table 2: Erythrogram of dystrophic lambs and kids compared to their control

\begin{tabular}{|c|c|c|c|c|c|c|}
\hline & & $\begin{array}{c}\text { RBCS } \\
\left(\times 10^{6} / \mu \mathrm{l}\right)\end{array}$ & $\begin{array}{c}\text { Hb } \\
\text { (g/dl) }\end{array}$ & $\begin{array}{l}\text { PCV } \\
(\%)\end{array}$ & $\begin{array}{c}\text { MCV } \\
\text { (fl) }\end{array}$ & $\begin{array}{c}\text { MCHC } \\
(\%)\end{array}$ \\
\hline \multicolumn{7}{|l|}{ Lambs } \\
\hline Control & $3-3.5$ & $8.36 \pm 0.08^{\mathrm{a}}$ & $14.80 \pm 0.11^{\mathrm{a}}$ & $44.80 \pm 0.13^{\mathrm{a}}$ & $53.55 \pm 0.43^{c}$ & $33.03 \pm 0.17^{\mathrm{a}}$ \\
\hline \multirow{2}{*}{ NMD } & $1-3$ & $5.46 \pm 0.48^{\mathrm{c}}$ & $10.66 \pm 0.83^{\mathrm{c}}$ & $35.60 \pm 2.30^{\mathrm{c}}$ & $65.20 \pm 3.17^{\mathrm{a}}$ & $29.94 \pm 0.74^{b}$ \\
\hline & $3-4$ & $6.73 \pm 0.09^{b}$ & $12.00 \pm 0.12^{\mathrm{b}}$ & $40.10 \pm 0.20^{\mathrm{b}}$ & $59.83 \pm 0.59^{b}$ & $29.92 \pm 0.14^{b}$ \\
\hline \multicolumn{2}{|c|}{ Sig. } & $* *$ & $* *$ & $* *$ & $*$ & * \\
\hline \multicolumn{7}{|l|}{$\underline{\text { Kids }}$} \\
\hline Control & $3-3.5$ & $7.40 \pm 0.05^{\mathrm{a}}$ & $14.20 \pm 0.11^{\mathrm{a}}$ & $40.46 \pm 0.29^{\mathrm{a}}$ & $54.69 \pm 0.81^{\mathrm{c}}$ & $35.08 \pm 0.04^{\mathrm{a}}$ \\
\hline \multirow{3}{*}{ NMD } & $1-2.5$ & $4.75 \pm 0.13^{b}$ & $10.50 \pm 0.17^{\mathrm{b}}$ & $32.00 \pm 0.57^{\mathrm{b}}$ & $67.36 \pm 1.43^{\mathrm{a}}$ & $32.81 \pm 0.11^{b}$ \\
\hline & $2.5-3.5$ & $5.96 \pm 0.03^{b}$ & $11.26 \pm 0.11^{\mathrm{b}}$ & $35.33 \pm 0.17^{\mathrm{b}}$ & $59.27 \pm 0.84^{b}$ & $31.87 \pm 0.59^{b}$ \\
\hline & & $*$ & * & $*$ & $*$ & $*$ \\
\hline
\end{tabular}

-Body Condition Scoring; BCS, Nutritional Muscle Dystrophy; NMD, Red Blood Cells; RBCs, Hemoglobin; Hb, Packed Cell Volume; PCV, Mean Corpuscular Volume; MCV, Mean Corpuscular Hemoglobin Concentration; MCHC. All data having different letters are differ significantly at $\mathrm{p}<0.05$. 

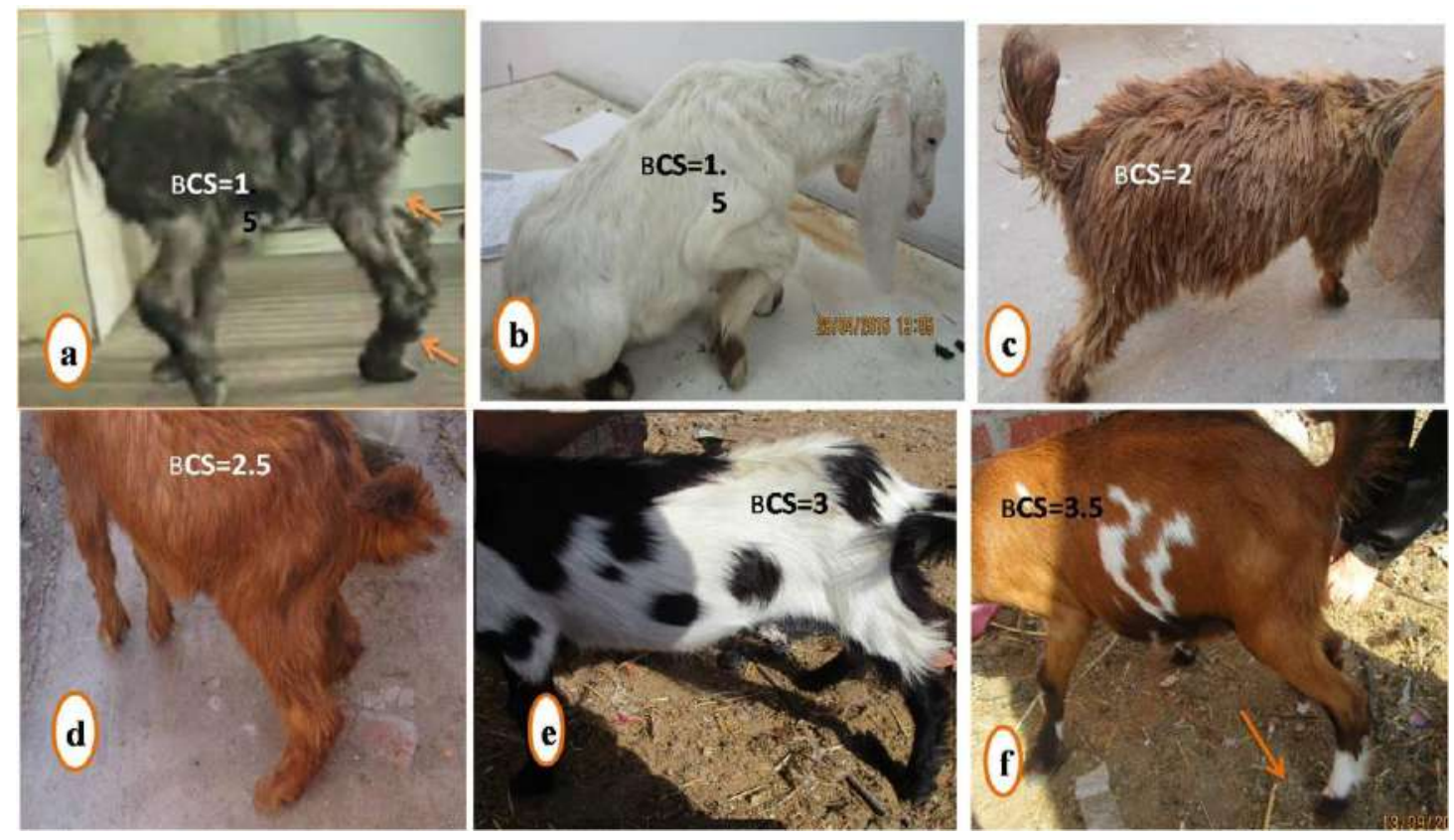

Figure 2: kids with BCS 1-3.5; knuckling on the fetlock with multiple deficiency signs (a), unable to stand (b, c, and d), twin kids; with help, stand on tip-toe (e) and arching the back, suffering from pain (f).

\section{Biochemical results}

Table (3) showed a significant $(\mathrm{P} \leq 0.05)$ decrease in the serum levels of vitamin $\mathrm{E}, \mathrm{Se}$, CAT, GSH-Px with a significant $(\mathrm{P} \leq 0.05)$ increase in the values of CPK, CTn1, MDA and NO besides non-significant changes in serum $\mathrm{Mg}$ level in dystrophic lambs when compared to the control group. These findings were higher in lambs with BCS 3-4 than those of 1-3. While in dystrophic kids, they showed a significant $(\mathrm{P} \leq 0.05)$ decrease in the serum levels of vitamin $\mathrm{E}, \mathrm{Se}, \mathrm{Mg}, \mathrm{CAT}, \mathrm{GSH}-\mathrm{Px}$ with a significant $(\mathrm{P} \leq 0.05)$ increase in the values of CPK, CTn1, MDA and NO, but with the same degree of severity in BCS 1-2.5 and 2.5-3. 


\begin{tabular}{|c|c|c|c|c|c|c|c|c|c|c|}
\hline BCS & & $\begin{array}{c}\text { Vit. E } \\
(\mu \mathrm{g} / \mathrm{ml})\end{array}$ & $\begin{array}{c}\text { Se } \\
(\mu \mathrm{g} / \mathrm{ml})\end{array}$ & $\begin{array}{c}\mathrm{Mg} \\
(\mathrm{mg} / \mathrm{dl})\end{array}$ & $\begin{array}{l}\text { CPK } \\
(\mathbf{U} / \mathbf{L}) \\
\end{array}$ & $\begin{array}{c}\text { CTn1 } \\
(\mathrm{ng} / \mathrm{ml})\end{array}$ & $\begin{array}{c}\text { MDA } \\
(\mathbf{n m o l} / \mathbf{m l})\end{array}$ & $\begin{array}{l}\text { CAT } \\
(\mathbf{U} / \mathbf{L}) \\
\end{array}$ & $\begin{array}{c}\text { GSH-Px } \\
(\mathbf{U} / \mathbf{L}) \\
\end{array}$ & $\begin{array}{c}\text { NO } \\
(\mu \mathrm{mol} / \mathrm{L})\end{array}$ \\
\hline \multicolumn{11}{|l|}{ Lambs } \\
\hline Control & $3-3.5$ & $1.06 \pm 0.11^{\mathrm{a}}$ & $0.160 \pm 0.013^{\mathrm{a}}$ & $2.44 \pm 0.18$ & $52.80 \pm 1.85^{\mathrm{c}}$ & $0.006 \pm 0.001^{\mathrm{c}}$ & $2.50 \pm 0.20^{\mathrm{c}}$ & $214.40 \pm 6.98^{\mathrm{a}}$ & $29.80 \pm 0.66^{\mathrm{a}}$ & $3.04 \pm 0.22^{\mathrm{c}}$ \\
\hline \multirow{2}{*}{ NMD } & $1-3$ & $0.49 \pm 0.06^{\mathrm{b}}$ & $0.070 \pm 0.010^{\mathrm{b}}$ & $2.16 \pm 0.31$ & $790 \pm 106.95^{\mathrm{b}}$ & $5.142 \pm 1.232^{\mathrm{a}}$ & $6.30 \pm 0.40^{\mathrm{b}}$ & $149.60 \pm 11.04^{b}$ & $13.40 \pm 1.21^{\mathrm{b}}$ & $8.40 \pm 0.42^{b}$ \\
\hline & $3-4$ & $0.20 \pm 0.02^{\mathrm{c}}$ & $0.008 \pm 0.001^{\mathrm{c}}$ & $2.44 \pm 0.14$ & $964 \pm 89.92^{\mathrm{a}}$ & $4.660 \pm 0.778^{b}$ & $8.32 \pm 0.31^{\mathrm{a}}$ & $130.60 \pm 3.22^{\mathrm{b}}$ & $9.00 \pm 0.71^{\mathrm{c}}$ & $9.88 \pm 0.55^{\mathrm{a}}$ \\
\hline \multicolumn{2}{|l|}{ Sig. } & $* *$ & $* *$ & NS & $* *$ & $* *$ & $* *$ & $*$ & $* *$ & $* *$ \\
\hline \multicolumn{11}{|l|}{ Kids } \\
\hline Control & 3-3.5 & $0.95 \pm 0.05^{\mathrm{a}}$ & $0.200 \pm 0.011^{\mathrm{a}}$ & $2.34 \pm 0.12^{\mathrm{a}}$ & $50.60 \pm 1.08^{b}$ & $0.007 \pm 0.002^{b}$ & $3.10 \pm 0.26^{\mathrm{b}}$ & $217.60 \pm 7.43^{\mathrm{a}}$ & $32.20 \pm 1.16^{\mathrm{a}}$ & $2.72 \pm 0.20^{b}$ \\
\hline \multirow{2}{*}{ NMD } & $1-2.5$ & $0.31 \pm 0.03^{b}$ & $0.015 \pm 0.004^{\mathrm{c}}$ & $1.28 \pm 0.25^{\mathrm{b}}$ & $896 \pm 89.92^{a}$ & $3.78 \pm 0.882^{\mathrm{a}}$ & $7.44 \pm 0.58^{\mathrm{a}}$ & $156.80 \pm 10.74^{\mathrm{b}}$ & $8.60 \pm 0.93^{\mathrm{b}}$ & $9.08 \pm 0.43^{\mathrm{a}}$ \\
\hline & $2.5-3.5$ & $0.20 \pm 0.03^{\mathrm{b}}$ & $0.082 \pm 0.009^{b}$ & $1.70 \pm 0.30^{\mathrm{ab}}$ & $814 \pm 82.74^{\mathrm{a}}$ & $2.680 \pm 0.292^{\mathrm{a}}$ & $8.28 \pm 0.32^{\mathrm{a}}$ & $153.80 \pm 9.67^{\mathrm{b}}$ & $11.00 \pm 0.71^{\mathrm{b}}$ & $8.42 \pm 0.30^{\mathrm{a}}$ \\
\hline Sig. & & $*$ & $* *$ & $*$ & $*$ & $*$ & $*$ & $*$ & $*$ & $*$ \\
\hline
\end{tabular}

- All data having different letters are differ significantly at $\mathrm{p}<0.05$.N.S; Non significant.

-Body Condition Scoring; BCS, Nutritional Muscle Dystrophy; NMD, Selenium; Se, Magnesium; Mg, Creatine Phosphokinase; CPK, Cardiac Troponin 1; CTn1, Malondialdehyde; MDA, Catalase; CAT, glutathione peroxidase; GSH-Px, Nitric oxide; NO 


\section{Discussion}

In the present study 38 of $51(74.5 \%)$ dystrophic animals were lambs, while kids resemble $25.4 \%$, this may be owed to the tendency of the owner in the study localities to breed sheep more than goats.

Sudden unaccustomed exercise as a predisposing cause for muscular dystrophy may be explained under the following base, high muscle activity causes a strong increase in ROS production which contains oxygen and are extremely reactive due to an unpaired electron. Among these oxygen, intermediates are the free radicals superoxide, peroxide and the hydroxyl radicals. They promote oxidation reactions with proteins, lipids, and DNA and can thus be highly detrimental, but the seeking for another factor than low selenium and vitamin $\mathrm{E}$ might be involved, as many field veterinarians suggested that metabolic stresses together with selenium and/or vitamin $\mathrm{E}$ deficiency are necessary for the clinical disease to occur [25].

Let us first agree that rapid growth is accompanied by increased metabolic rate, and thus oxygen consumption, as the growth is highly physiologically demanding. Therefore, the rapidly growing animal may be exposed to relatively more ROS which may impair the physiological functions in the body and reduce survival and fitness [26, 27]. In rapidly growing lamb, oxidative stress increases, high MDA levels appeared to be related to faster growth but have little impact on subsequent survival, so, the associations between oxidative stress markers, growth and survival are highly marker and context dependent [28].

It is clear that the problem was more quickly, common, and serious in the lambs with BCS 3-4, as their requirements should be increased especially from antioxidants [29]. While the occurrence of the disease in kids was more common in BCS 1-2.5, which clear that mainly poor nutrition is the cause of the disease, as such animals usually suffer from multi deficiencies.

Goats like other ruminants have little ability to manage magnesium level in the blood if dietary levels or absorption are depressed.
With the exertion of muscle during fits of hypomagnesemia, the disease appears. Ill thrift lamb and goat with BCS 1 and 2 that under dietary inadequacies usually develop multi vitamins and minerals deficiencies, signs of copper and iron deficiency that usually concurrent with signs of vitamin $\mathrm{E}$ and selenium deficiency in such cases. A relationship between hypomagnesemia and muscular dystrophy in calves was reported by Dehority and Rouss [30]. Additionally, Tollersrud [31] recorded that supplementation with magnesium prevents the development of NMD in calves with vitamin E deficiency.

Vitamin E and Se deficiency affect both the skeletal and cardiac muscles. When the skeletal muscles are affected, symptoms vary from stiffness in gait, to an inability to stand and recumbency. Cardiopulmonary signs usually appear due to the involvement of the heart and muscle of respiration, the diaphragm and intercostals muscles [32].

As an essential trace element, vitamin $\mathrm{E}$ and selenium (Se) are important in humans and animals and their deficiency has caused many health problems. Se is an important component of the antioxidant enzymes, such as glutathione peroxidase (GPx), iodothyronine deiodinases (IDD) and thioredoxin reductase (TrxR). Se-containing proteins (selenoproteins) or enzymes (selenoenzyme) [33] have strong antioxidant activity include six groups of the GPx(GPx 16). These GPx play an essential mechanism in protecting cells against oxidative damage from reactive oxygen species (ROS) and reactive nitrogen species (RNS), which include hydroxyl radicals, superoxide, nitric oxide, hydrogen peroxide and peroxynitrite [34,35]. Thus, vitamin $\mathrm{E}$ and Se deficiency in lambs and kids resulted in a significant decrease in the serum level of GSH-Px and CAT enzymes and significant elevation of lipid peroxidation; MDA and nitric oxide [36,37]. A similar result was also recorded by Ghanem et al. [9].

ROS are highly reactive radicals which secreted from neutrophils and macrophages and pushed into the plasma to be neutralized before they can be taken up by RBCs. RBCs are extremely exposed to endogenous and 
exogenous ROS that have shown to damage the RBC membrane [38,39]. All the above may discuss our results which revealed that lambs and kids showed signs of anemia [40].

NMD is a non-inflammatory destructive disease affecting cardiac and skeletal muscle. In a veterinary flock, cardiac troponins are sensitive indicators of myocardial damage caused by cardiac and/or non-cardiac reasons [41]. In sheep medicine, there are few articles about the diagnostic value of cTnI such as experimental cardiac disease in comparative studies and others in the diagnosis of acute white muscle disease [42]. Lowering of serum vitamin $\mathrm{E}$ and selenium concentrations resulted in an increase in creatine kinase $(\mathrm{CK})$ activities and troponin 1 concentrations. Our results revealed significant elevations in cTn I and CPK in dystrophic lambs and kids were similarly to those obtained by Tunca et al. [43], Ataollahi et al. [44] in lambs and Tharwat et al. [45] in kids.

\section{Conclusion}

It could be concluded that proper nutrition of dam and young without shortage or excess is necessary; also, vitamin $\mathrm{E}$ and se supplementation should be increased in good bodily conditioned and rapidly growing animals than their counterparts to activate the antioxidant system and reduce oxidative stress. Magnesium deficiency may be considered a predisposing cause for muscular dystrophy, especially in kids. Lamb and kids are viewed differently in their Vitamin $\mathrm{E}$ and $\mathrm{Se}$ metabolism and requirements.

\section{Conflict of interest}

None of the authors have any conflict of interest to declare.

\section{Acknowledgments}

The authors thank sheep and goat owners for their co-operation. There was no fund received for the study.

\section{References}

[1] Pugh, D. G. and Baird, N. (2012): Sheep and Goat Medicine, 2nd Edition.640 p.

[2] Ramirez, B. E.; Hernandez, C. E.; Hernandez, C. L. M. and Tortora, P. J. L.
(2004) : Effect of parenteral supplement with sodium selenite on lamb mortality and hematic values of selenium. Agrociencia, 38:43-51.

[3] Ramirez, B. E.; Tórtora, J. L.; Huerta, M.; Hernández, L. M.; López, R. and Crosby, M. (2005): Effect of selenium-vitamin E injection in selenium-deficient dairy goats and kids on the Mexican plateau. Arq. Bras. Med. Vet. Zootec., 57: 77-84.

[4] Khidr, B.M.; Mekkawy, I.A.A.; Harabawy, A.S.A. and Abdel Salam, M.I. (2008): Effect of separate and combined lead and selenium on the liver of the cichlid fish Oreeochromis niloticus: Ultrastructural Study. Egypt. J. Zool., 50: 89-119.

[5] Zubair, M.; Ali, M.; Ahmad, M.; Sajid, S.M.; Ahmad, I. and Gul, S. T. (2015): Effect of selenium and vitamin $\mathrm{E}$ on cryopreservation of semen and reproductive performance of animals (a review). J. Entomol. Zool. Studies, 3(1): 82-86.

[6] Diplock, A.T. (1981): Metabolic functional defects in selenium deficiency. Philos. Trans. R. Soc. Lond. B., 294:105-117.

[7] Robson, S.; John, P. and Geoff, C. (2016) : Selenium deficiency in sheep. Primefact 471, 3rd ed.

[8] Scott, P.R. (2007): Sheep medicine. In metabolic disorder and elements deficiencies. Manson publishing Ltd. Spain.

[9] Ghanem, M. M.; Anwar, M. R.; Abd ElRaof, Y. M. and El-Attar H.M. (2016): Clinical, hematological and biochemical changes in lambs suffered from nutritional muscular dystrophy. Benha Vet. Med. J., 30(2):61-66.

[10] Pennington, J. (2010) : Body condition scoring of sheep and goats. University of Missouri, Lincoln University, U.S. Department of Agriculture and Local Extension Councils Cooperating.

[11] Koyuncu, M. and Altınçekiç, Ş. Ö. (2013): Importance of body condition score in dairy goats. Maced. J. of Anim. Sci., 3(2): 167-173. 
[12] Sherman, D.M. and Robinson, R. A. (1983): Clinical examination of sheep and goats. The Veter. Clinics of North America Large Anim. Pract., 5: 409-426.

[13] ESGPIP, (2007): Body Condition Scoring of Sheep and Goats. Technical Bulletin No. 8. www.esgpip.org/ PDF/Technical\%20bulletin\%20No8.html . Accessed from internet on Saturday, March 04/2017.

[14] Grindem, C. B. (2011): Schalm's Veterinary Hematology, 6th edition. Editors: Douglas J. Weiss, K. Jane Wardrop.

[15] Chawla, R. and Kaur H. (2001): Isocratic HPLC method for simultaneous determination of $\mathrm{B}$ carotene, retinol and a tocopherol in feeds and blood plasma. Ind. Dairy Sci. J., 54:84-90.

[16] Sunderman, F. W. and Roszel, N. O. (1967): Measurement of copper in biological materials by atomic absorption spectrometry, Am. J. Clin. Pathol., 48:286.

[17] Burtis, C.A.; and Ashwood, E.R. (1994): Tietz Textbook of Clinical Chemistry, 2nd ed. Philadelphia, PA: WB Saunders,:1913 p.

[18] Kennedy, J.W.; Carey, R.N. and Coolen R.B. (1999): Evaluation of Precision Performance of Clinical Chemistry Devices; Approved Guideline (EP5-A). Wayne, PA: The National Committee for Clinical Laboratory Standards.

[19] Hochholzer, W.; Reichlin, T.; Twerenbold, R.; Stelzig, C.; Hochholzer, K.; Meissner, J.; Haaf, P.; Schaub, N.; Steuer, S. and Bassetti, S. (2011): Incremental value of high-sensitivity cardiac troponin $\mathrm{T}$ for risk prediction in patients with suspected acute myocardial infarction. Clin. Chem., 57: 1318-1326.

[20] Ohkawa, H.; Ohishi, N. and Yagi, K. (1978): Assay for lipid peroxides in animal tissue by thiobarbituric acid reaction.

Analytical
[21] Aebi, H. (1984): Catalase in vitro. Methods Enzymol. 105:121-126.

[22] Paglia, D.E. and Valentine, W.N. (1967): Studies on the quantitative and qualitative characterization of erythrocyte glutathione peroxidase. Lab. Clin. Med., 70: 158-169.

[23] Beda, N and Nedospasov A. (2005): A spectrophotometric assay for nitrate in an excess of nitrite. Nitric oxide: Bio. and Chem., 13: 93-97.

[24] Duncan, D. B. (1995): Multiple ranges and multiple F test Biometrics, 11:1- 42.

[25] Allen, J. G.; Steele, P.; Masters, H. G. and D'antuonot, M. F. (1986): A study of nutritional myopathy in weaner sheep. Aust. Vet. J., 63: 803-806.

[26] 26. Beckman, K.B. and Ames, B.N. (1998): The free radical theory of aging matures. Physiol. Rev., 78:547-581.

[27] Monaghan, P.; Metcalfe, N.B. and Torres, R. (2009): Oxidative stress as a mediator of life history trade-offs: mechanisms, measurements and interpretation. Med. Vet. Zootec., 57: 77-84.

[28] Christensen, L.L.; Selman, C.; Blount, J.D.; Pilkington, J.G.; Watt, K.A.; Pemberton, J.M.; Reid, J.M. and Nussey D.H. (2016) : Marker-dependent associations among oxidative stress, growth and survival during early life in a wild mammal. Proc. Biol. Sci., 12:283.

[29] Leal, M.L.; de Camargo, E.V.; Ross, D.H.; Molento, M.B.; Lopes, S.T. and da Rocha, J.B. (2010) : Effect of selenium and vitamin $\mathrm{E}$ on oxidative stress in lambs experimentally infected with Haemonchus contortus. Vet. Res. Commun., 34(6):549-55.

[30] Dehority, B. A. and Rouss, E. (1961): Effects of addition of magnesium, tocopherol and cod liver oil to a whole milk diet on some biochemical constituents in serum, soft tissue, and bone of calves. J. Dairy Sci., 44: 58-84. 
[31] Tollersrud, S. (1963): Ernaeringsbetinget muskeldystiofihoskalv. Nord. Vet. v5: 543- 551.

[32] Faerber, C. W. (2004): Small Ruminant Production Medicine \& Management (Sheep and Goats), 3rd Edition. Animal Health Publications, Brigham City, UT 84302.

[33] Tapiero, H.; Townsend, D.M. and Tew, K.D. (2003): The antioxidant role of selenium and seleno-compounds. Biomed. Pharm., 57:134-44.

[34] Klotz, L.O.; Kroncke, K.D.; Buchczyk, D.P. and Sies H. (2003): Role of copper, zinc, selenium, tellurium in the cellular defense against oxidative and nitrosative stress. J. Nutr., 133:1448S-51S.

[35] Valko, M.; Rhodes, C.J.; Moncol, J.; Izakovic, M. and Mazur, M. (2006): Free radicals, metals, antioxidants in oxidative stress-induced cancer. Chem. Biol. Interact., 160:1-40.

[36] Pietro, C. (2010): The role of oxidative stress in small ruminants' health and production. Revista Brasileira de Zootecnia, 39: 348-363.

[37] Alhidary, I.A.; Shini, S.; Al Jassim, R.A.; Abudabos, A.M. and Gaughan J.B. (2015): Effects of selenium and vitamin $\mathrm{E}$ on performance, physiological response, and selenium balance in heatstressed sheep. J. Anim. Sci., 93(2):576588 .

[38] Nagababu, E.; Gulyani, S.; Earley, C. J.; Cutler, R. G.; Mattson, M. P. and Rifkind, J. M. (2008): Iron-deficiency anaemia enhances red blood cell oxidative stress. Free Radic. Res., 42:824-829
[39] Barodka, V. M.; Nagababu, E.; Mohanty, J.G.; Nyhan, D.; Berkowitz, D. E. and Rifkind J. M. (2013): New insights provided by a comparison of impaired deformability with erythrocyte oxidative stress for sickle cell disease. Blood Cells Mol. Dis., 52(4):230-235.

[40] Koller, L.D. and Exon J.H. (1986): The two faces of selenium-deficiency and toxicity-are similar in animals and man. Can. J. Vet. Res., 50(3):297-306.

[41] Wells, S.M. and Sleeper, M. (2008): Cardiac troponins.J. Vet. Emerg. Crit. Care, 18:235-245.

[42] Leonardi, .F; Psseri, B.; Fusari, A.; Derazza, P.; Beghi, C.; Lorusso, R.; Corradi, A. and Botti, P. (2008) : Cardiac Troponin I (cTnI) concentration in an ovine model of myocardial ischemia. Res. Vet. Sci., 85:141-144.

[43] Tunca, R.; Erdogan, H. M.; Sozmen, M.; Mehmet, Ç.; Devrim, A. K.; Erginsoy, S. and Uzlu, E. (2009) : Evaluation of cardiac troponin I and inducible nitric oxide synthase expression in lambs with white muscle disease. Turk. J. Vet. Anim. Sci., 33:53-59.

[44] Ataollahi, F.M.; Mohri, M. H. and Seifi, A. (2013): Diagnostic value of cardiac troponin I (cTnI), creatine kinase (CK), and aspartate amino transferase (AST) in selenium deficiency in lambs. Revue Méd. Vét., 164(4): 207-211.

[45] Tharwat, M.; Al-Sobayil, F. and Mehana EL-SAYED, M. (2013): Cardiac troponin I in healthy newborn goat kids and in goat kids with cardiac nutritional muscular dystrophy. Acta Veterinaria Hungarica, 61 (4):442-45 


$$
\text { الملخص العربي }
$$

المؤشرات الحيوية للاجهاد التأكسدي في الحملان وصغار الماعز المصابة بالاضمحلال العضلي وعلاقته بتصنيفات حالة الجسم

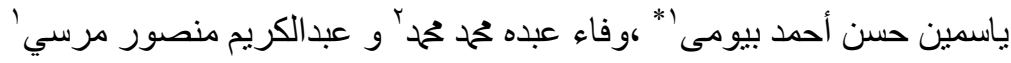

$$
\begin{aligned}
& \text { ' قسم طب الحيو ان( مادة الأمر اض الباطنه)- كلية الطب البيطري- جامعة الزقازيق }
\end{aligned}
$$

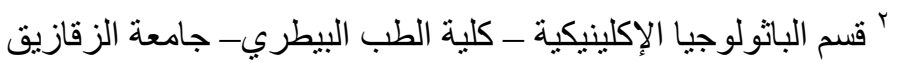

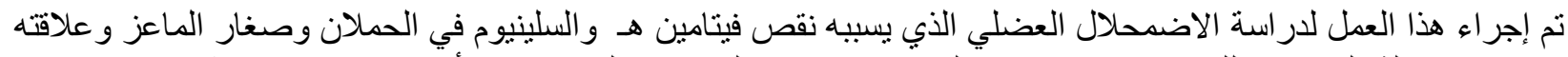

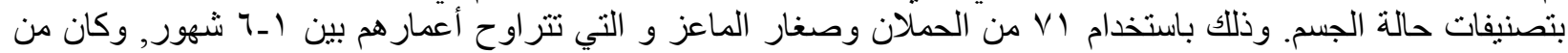

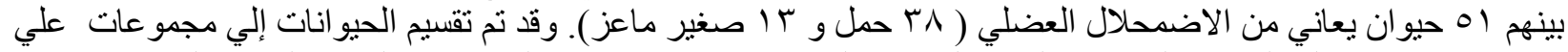

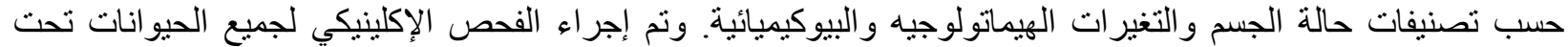

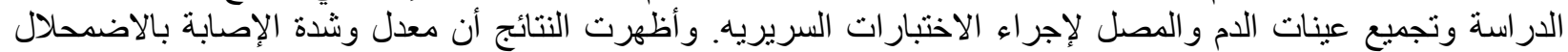

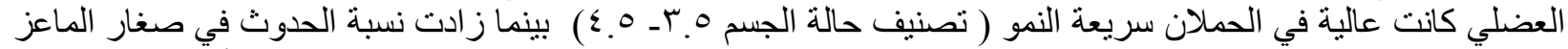

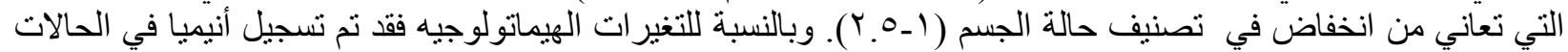

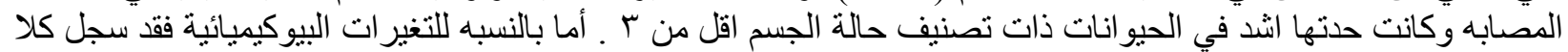

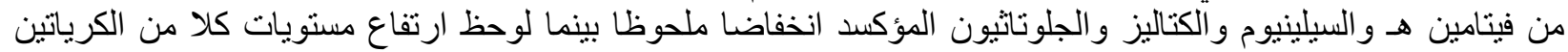

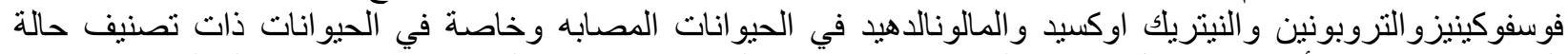

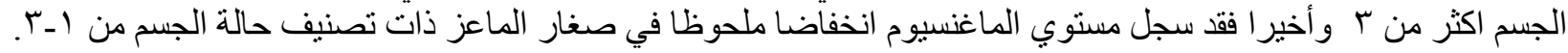

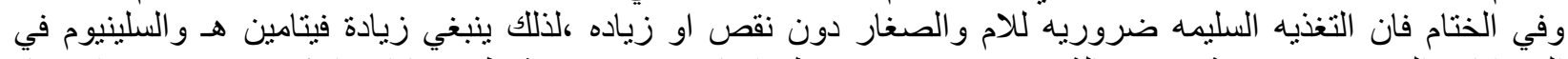
الحيو انات التي تنمو بسرعة وفي حالة جسميه جيده عن نظير اتها حتي تقوم بتنشيط مضادات الاكسده وتحد من الإنيا الإجهاد 